\title{
Economics of marketing and constraints in emu farming in Marathwada region of Maharashtra state
}

V.G. LANDGE, D.N. HEDGIRE, R.A. KOLAMBKAR AND P.R. MULE

Received : 13.08.2014; Accepted : 25.09.2014

\begin{abstract}
The data on selected economic aspects were collected by interviewing the respondent farmers in the Marathwada region of Maharashtra state. Cost of marketing of eggs incurred by sampled emu farmers was Rs. 4420 where as cost of marketing of eggs incurred by emu farmer was Rs. 4620 . The majority of the farmers $(85.71 \%)$ reported that low price for emu product, lack of organized market $(71.43 \%)$, followed by high cost of emu bird feed $(42.86 \%)$, carelessness in medicinal services by emu farmers $(14.29 \%)$ were the constraints faced by emu farmers.
\end{abstract}

KEY WORDS : Emu farming, Economics, Marketing, Constraints

How to cite this paper : Landge, V.G., Hedgire, D.N., Kolambkar, R.A. and Mule, P.R. (2014). Economics of marketing and constraints in emu farming in Marathwada region of Maharashtra state. Internat. J. Com. \& Bus. Manage., 7(2) : 417-419.

\section{MEMBERS OF THE RESEARCH FORUM}

Correspondence to:

V.G. LANDGE, Department of Agricultural Economics, College of Agriculture, Vasantrao Naik Marathwada Krishi Vidyapeeth, PARBHANI (M.S.) INDIA

Email: varshalandge002@gmail.com

Authors' affiliations:

D.N. HEDGIRE AND R.A. KOLAMBKAR, Department of Agricultural Economics, College of Agriculture, Vasantrao Naik Marathwada Krishi Vidyapeeth, PARBHANI (M.S.) INDIA

P.R. MULE, Department of Animal Husbandry and Dairy Science, College of Agriculture, Vasantrao Naik Marathwada Krishi Vidyapeeth, PARBHANI (M.S.) INDIA 